\title{
Development of means to improve productive health in dairy cattle breeding
}

\author{
Nikolay Zuev*, Valentina Breslavets, Vitaly Shumsky, Alexander Breslavets, and Ivan
} Furmanov

Belgorod State Agricultural Univerisity named after V. Gorin, pos. Mayskiy, Russia

\begin{abstract}
In this article the treatment method of osteodystrophy in cows by oral administration of mineral-sorption vitamin additive "Carbosil AD" (consisting of zeolite, bentonite, hydrated soluble silicon and calcium carbonate with forage forms of vitamins A and D) is studied. And its effect on haematological, hepatological, productive indicators, calcium deficiency.
\end{abstract}

\section{Introduction}

Recently, when the country has long solved the problem of food supply, the issue of improving the quality of consumed products is becoming more and more acute. Introduced new standards and different brands to find their customers. Dairy products are the most important and largely determine the health of the nation, has not always been mandatory for all residents of our country. If the production and consumption of milk in the Soviet Union was ahead of the U.S., but now on these indicators, we lag behind even many European countries. First of all, keeping cows on private plots has been almost completely eliminated. Earlier, every able-bodied farmer had a cow, but now this valuable animal is becoming exotic. Production and consumption of milk and dairy products, leaves much to be desired.

In recent years, in terms of poultry and pork production, the country has transformed from an imported to an exported country in these products. But we still lag behind many European and some countries of the former Soviet Union in production of milk and dairy products.

These problems are solved in the country by creating large dairy complexes, holdings with concentration of a large number of highly productive, often Holstein-Friesian cattle. Breeding high-productive animals are imported to the country and are constantly being imported. But industrial technology of keeping and feeding of these animals does not always provide maximum using of biological potential and getting of high-quality milk. One of the problems of such animals is metabolic disorders, manifested by the appearance of osteodystrophy in cows, which leads to a reduction in the period of use of these valuable animals and a decrease in the quality of the products obtained.

While carrying out researches on improvement of treatment and prophylaxis of osteodystrophy in cows scientific and economic experience was carried out. We have

\footnotetext{
*Corresponding author: zuev_1960_nikolai@mail.ru
} 
established that application of mineral-sorption-vitamin additive with use of raw materials of local production, has allowed to receive reliable therapeutic effect, considerably to improve quality of milk, to raise productivity of animals. It is proved that adding to the ration of cows with symptoms of osteodystrophy during 60 days the mineral-sorptionvitamin addition consisting of $150 \mathrm{~g}$ carbosyl, $0.1 \mathrm{~g}$ vitamin A (50000 IU) and $0,1 \mathrm{~g}$ vitamin D (100000 IU) of forage forms promoted increasing: productivity by $17 \%$, fat content by $10.2 \%$, protein content in milk, reducing of somatic cells in milk. Thus, the proposed mineral-sorption-vitamin additive using locally produced raw materials provides not only therapeutic effect, increases animal productivity, but also significantly improves the quality of this valuable, so necessary for each of us obtained product.

It should be noted that the reserves of raw materials and production capacity can provide this valuable additive not only to livestock in Belgorod region, but also to other regions of the country.

Dairy cattle breeding is the most complex branch of livestock breeding and solves the most important problem - providing the country's population with milk and dairy products, so necessary for each of us. In the country and especially in our region, almost completely eliminated the maintenance of cows in farmsteads, which produced a huge part of the milk. At the moment the agro-industrial complex of the country is allocating billions of dollars to solve this complicated and important problem. We are far behind many European countries and some Soviet republics (Belarus, Baltic) in production and consumption of milk and dairy products, having surpassed the USA in the Soviet past. Many tens of thousands of pedigree high-productive cattle were brought into the country. Large dairy complexes, holdings where thousands of highly productive cows of mainly Holstein-Friesian breed are concentrated have been established. But the conditions of industrial technology do not always ensure the maximum use of the biological potential of the animals. The slightest violations of the conditions of maintenance and feeding lead to various pathologies, as a result, the animals are prematurely culled.

It is known that a cow reaches maximum productivity by 5-6 years of lactation. In reality, in dairy complexes and holdings, cows live 2-3 lactations. One of the most frequently diagnosed pathologies is alimentary osteodystrophy, which we detected in all dairy complexes of the region.

We have conducted researches on the improvement of treatment and prophylaxis of this pathology in high-yielding cows in conditions of industrial dairy complex.

\section{Material and methods of research}

Scientific and economic experiment was carried out in the conditions of the industrial dairy complex of the collective farm named after Gorin. The experiment was conducted on cows in which osteodystrophy was diagnosed. The isolated cows were divided into three groups, 8 cows in each group. The cows of the first control group were fed the basic ration, the second group cows were fed $150 \mathrm{~g}$ of Karbosil once a day and the third group cows were fed $150 \mathrm{~g}$ of mineral-sorption vitamin additive "Carbosil AD". The preparations were introduced into the feed 10 days before calving and 40 days after calving. The cows were monitored taking into account the clinical condition, forage eating ability, productive indicators. Productive indicators were taken into account after the milking period ( 5 days after calving) for 35 days.

The sorption agent consists of $15-25 \%$ zeolite, $15-30 \%$ bentonite, $5-25 \%$ hydrated soluble silicon and $40-45 \%$ calcium carbonate. The defect of mineral lattice predetermines biological activity of the preparation. Significant sorption properties are provided by high porosity of the mineral. 
The therapeutic mixture was prepared at the rate of $1.5 \mathrm{~kg}$ of carbosil, $1 \mathrm{~g}$ of vitamins A and $\mathrm{D}$ was added. The supplement was fed to cows daily during 60 days, 10 days before and 60 days after calving.

To study the effect of mineral-sorption vitamin feed additive on biochemical blood parameters, four cows in each of three groups were selected. Cows of the control first group did not receive the supplement. The cows of the second group were fed the mineral-sorption supplement "Carbosil AD" at the dose of $150 \mathrm{~g}$ during 50 days. Cows of the third group received daily, within 50 days $150 \mathrm{~g}$ of mineral sorption vitamin additive "Carbosil AD" with feed. Blood samples from cows were taken before the experiment and after 50 days.

\section{Research results}

The conducted studies established that the main symptoms of the disease were: softening of the last caudal vertebrae, wobbling of incisor teeth, softening and wobbling of transverse processes of lumbar vertebrae. All experimental animals exhibited rumen hypotonia and increased acidity of the rumen contents.

When analyzing the conditions of keeping and feeding the cows, it was found out that the animals do not use sufficiently the motions, insolation, there was a deficit of carotene, vitamin $\mathrm{A}$ and especially vitamin $\mathrm{D}$ in the rations.

We developed and proposed mineral-sorption-vitamin additive from locally produced raw materials. The additive was prepared by mixing carbosil with feed forms of vitamins A and D, $0.1 \mathrm{~g}$ of vitamin A (50000 IU) and 0.1 vitamin D (100000 IU) were added per $150 \mathrm{~g}$ of carbosil (effective dose).

While observing taking into account clinical condition, feed eatability, productive indices which were taken into account after milking period during 45 days it was established that cows receiving the studied additive had mineralization of tail vertebrae, shaky incisors disappeared, the number of rumen contractions increased up to the norm and acidity of rumen contents decreased by $25.3 \%$. It has been established that the cows receiving the studied additive have increased: productivity by $17 \%$, fat content by $10.2 \%$, protein content in milk by $8 \%$, the content of somatic cells has decreased by $4.4 \%$.

Hematological studies revealed that in animals receiving the studied additive normalized phosphorus-calcium metabolism. The blood content of protein and especially albumin increased, which correlated with an increase in productivity of these animals.

Dynamics of aminotransferases (AST and ALT) and de-Rithis coefficient indicate improved liver function in cows receiving the supplement. This is confirmed by the reduction of bilirubin level in blood serum by $56.3 \%$ compared to the control and some reduction of creatine.

Thus, application of mineral-sorption vitamin additive to cows at alimentary osteodystrophy in a dose of $150 \mathrm{~g}$ within 60 days provides therapeutic effect, increases productivity of cows improves milk quality. The supplement is prepared from raw materials of Belgorod region, technical capabilities allow to provide this valuable supplement not only to cattle breeding in Belgorod region, but also to other regions of the country.

Dynamics of manifestation of clinical symptoms of osteodystrophy at application of mineral-sorption vitamin supplement "Carbosil AD".

Obtained results of the study indicate that softening of caudal vertebrae was observed in all experimental cows, shakiness of incisor teeth was registered in 37.5$50 \%$ of cows, rumen hypotonia and decrease in $\mathrm{pH}$ of rumen contents were observed in all cows. In clinical examination of cows after 50 days it was found that control cows had further development of osteodystrophy - softening of caudal vertebrae 
continued, staggering of teeth by $25 \%$ increased, disturbance of gastrointestinal tract was noted.

In cows of the second group receiving the supplement "Carbosil AD", the following was registered: in $50 \%$ of cows mineralization of tail vertebrae and disappearance of teeth wobbling. In addition, signs of rumen hypotonia disappeared and acidity of rumen contents decreased.

The best results of researches were noted in cows of the third group which were daily fed mineral-sorption vitamin additive during 50 days. These cows had complete mineralization of tail vertebrae, shakiness of incisor teeth disappeared, the number of rumen contractions increased and the acidity of rumen contents decreased.

First of all, it was established that all cows increased productivity by $75-91 \%$. At the same time, the greatest increase in productivity was noted in the cows of the third (2nd experimental) group, which received mineral-sorption vitamin additive "Carbosil AD" - by $17.2 \%$ more in comparison with the control. The fat content of milk in the cows of the 2 nd experimental group increased by $10.2 \%$, protein content by $8.0 \%$. Somatic cells in the milk of the control cows were $4.4 \%$ more compared to the cows of the third group.

It should be noted that all cows had increased albumin content in blood serum by the end of the experiment, which correlates with an increase in cow productivity. But the greatest increase in the content of albumin was noted in cows receiving mineralsorption vitamin supplement - (by $14.2 \%$ more compared with the control). The dynamics of total protein in blood serum was somewhat different. If in control cows the content of total protein in blood serum increased by $5.3 \%$, in cows receiving mineral-sorption and mineral-sorption vitamin additive the content of total protein in blood serum decreased by 12.9 and $13.8 \%$ respectively.

This also manifested itself in changes in the activity of liver enzymes aminotransferases. Thus, if the level of ALT (alanine aminotransferase) increased most of all in control cows (by 28\%). Although not exceeding normal values, ACT (aspartate aminotransferase) content in the cows fed mineral-sorption and mineralsorption vitamin supplements decreased by 14.3 and $21.2 \%$ respectively, which could not but affect de-ratios, which in all cows was higher than normal.

At the end of the experiment this coefficient decreased most in cows receiving mineral-sorption vitamin supplement $(41.1 \%)$. In the same cows the level of bilirubin decreased by $2.28 \%$. All this indicates that the use of feed and mineral-sorption vitamin supplement improves the performance of the liver. Significant changes underwent and phosphorus-calcium metabolism. If in control cows the content of total calcium in blood serum remained almost unchanged and was below the physiological norm, then at administration of mineral-sorption and especially mineral-sorption vitamin supplements the calcium content in blood serum increased by 33.3 and $41.0 \%$ respectively and reached the physiological norms. The content of inorganic phosphorus in blood serum in all cows was within the physiological norm. And the ratio of calcium to phosphorus in cows taking supplements was close to the norm. The content of iron in blood serum has slightly increased that quite correlates with the increase and approaching to the norm of the content of hemoglobin in blood. At intake of mineral-sorption vitamin supplementation the content of glucose in the blood reliably increased. If in control cows at the end of the experiment the level of glucose remained almost unchanged, the glucose content in cows of the 3rd experimental group increased by $22.8 \%$. 


\section{Conclusion}

Thus, the way of treatment of osteodystrophy in cows by means of oral application of mineral-sorption vitamin additive "Carbosil AD" in a doze of $150 \mathrm{~g}$ once a day during 50 days has been offered and application of mineral-sorption vitamin additive "Carbosil AD" in a doze of $150 \mathrm{~g}$ per cow in a day, during 50 days is highly effective for treatment of the cows having osteodystrophy. Application of the additive also increases productivity of cows by $15.6 \%$, improves the quality of milk, (increases the fat content of milk by $21.0 \%$, the protein content by $15.1 \%$ ).

\section{References}

1. N.V. Bezborodov, A.Yu. Avdeev, V.N. Pozdnyakova, Bulletin of the Orenburg State Agrarian University, Orenburg, 2 (46), 98-100 (2014)

2. T.V. Agalakova, The physiological rationale for the use of biologically active drugs to intensify the reproduction of cattle, Nizhny Novgorod, (2011)

3. A.A. Aliev, G.E. Petrov, A.N. Grigoryev, Dokl. UPPER, 9, 36-39 (1991)

4. L.N. Berdnikova, Influence of various factors on the productive dollety of cows of red-motley breed, 18 (Krasnoyarsk, 2007)

5. V.A. Vitol, Development of new methods to increase the reproductive qualities of the breeding stock of cattle, 19 (Krasnodar, 2010)

6. G.S. Vlasov, The effectiveness of the use of biotechnological methods for controlling the reproductive function of dairy cows, 19 (St. Petersburg-Pushkin, 2006)

7. E.S. Voronin, A.M. Petrov, M.M. Serykh, D.A. Dervishev, Immunology 408 (M, Kolos - Press, 2002)

8. N.M. Glazunova, N.V. Bezborodov, Russian Veterinary Journal, "Kolos, 36-38 (2007)

9. M.I. Klopov, V.V. Arepiev, O.V. Pershina, Neurohumoral regulation of physiological systems and the metabolism of organic substances in animals, Moscow, 162 (2012)

10. I.P. Kondrakhin, Methods of veterinary clinical laboratory diagnostics, 520 (M. KolosS, 2004)

11. A.F. Kuzmin, G.L. Sologub, N.P. Bugaev, Blood counts in cows at different periods of reproductive function, 46, 211-212 (1976)

12. V.V. Menshikov, L.N. Delektorskaya, R.P. Zolotnitskaya, et al. Laboratory methods of research in the clinic: Handbook, 368 (M. Med., 1987)

13. A.I. Ovsyannikov, Fundamentals of experimental work in animal husbandry, 304 (M., "Ear", 1976)

14. N.I. Polyantsev, Zootechnics 6, 29-30 (1999)

15. M.I. Prokofiev, Tr. Institute of physiology, biochemistry and nutrition, agricultural institute animals 27, 3-11

16. V.N. Romanoman, I.A. Boyko, Bulletin Kras. GAU, Krasnoyarsk 4, 144-149 (2015)

17. R.M. Khaitov, B.V. Pinegin, Clinical. medicine 8, 7-12 (1999) 
18. E.O. Cherepchenko, NV Bezborodov, Adaptation-compensatory mechanisms of triggering sexual cyclicity in cows with hypofunction of the ovaries, after the introduction of the immunocorrector thymogen, 1 st Congress of Pharmacologists, 622-628 (VNIVIPPiT - Voronezh, 2007)

19. Chuev N.V., Bezborodov, Bulletin of the Krasnoyarsk State Agrarian University, 12, 158-164 (2014)

20. B. Alberts, Molecular biology of the cell, 1244 (New York, 1994)

21. K.L. Anderson, Fm. J. Vet. Res., 44, 677-680 (1983)

22. E. Baral, Cancer 75, 591-599 (1995) 